\title{
MUSIC PRINCIPLES AS HELP FOR THE STRUCTURAL MODEL OF A SCHOOL LESSON
}

\author{
Jana Konvalinková
}

\begin{abstract}
Annotation
The powers of thought, emotion, and will are seminal elements of human personality. Purposeful work with these elements in the teaching process is conducive to deeper understanding and absorption of the curricular subject matter, as well as influencing long-term memory, and stimulating creativity. Let's therefore draw up an imaginary structural model of a school lesson built upon these very principles.
\end{abstract}

\section{Key words}

Music, school lesson, structural model of a school lesson, Waldorf pedagogy.

I took the basic elements of the Waldorf Method as the starting point of my paper on creativity in the approach of a primary education teacher.

As I am now going to draw on the principles established by the Waldorf Method in education, I believe it will be useful to start by a brief outline of the history of this alternative movement in schooling.

The first Waldorf school was established in 1919. Its foundation should be viewed from the perspective of the broader economic and political context, of Central Europe devastated in the aftermath of the First World War and marked by the collapse of the former state entities on whose territories a lot had to start anew from the scratch. This also applied to schools that stood vis-à-vis the inevitable decision on whether to carry on implementing timetested thought patterns, or rather to try and set up new systems that would be tuned to the exigencies of the time. This was a time of an immense boom of innovative teaching methods: one should recall here the work of Marie Montessori in Italy, as well as the fact, in the same year as the Waldorf school came into existence, Helen Parkhurst formed an experimental school in Dalton (the method being since then referred to as the Dalton Plan), and there were others, including Peter Petersen's Jena Plan, or the French 
country teacher, Célestin Frenet (1896-1966), spiritual father of the Freinet teaching method.

The Austrian industrialist, Emil Molt, owner of the Waldorf Astoria cigarette factory, asked Rudolf Steiner to set up a school structured in accord with the new makeup of society at large, which would cater to the offspring of the company's staff, managers and blue-collar work force alike. The system was to comply with Molt's urgent call for the introduction of an education system that would bridge the gap between the classes instead of deepening it. Basing himself on his own spiritual studies, Rudolf Steiner invented a teaching method which set before itself the goal of bringing up a harmonious and all-round human being whose will, intellectual powers and emotions would be equally balanced and would thus become an asset for society as a whole. In his endeavor, he drew on his own concept of the development of the human individual on a time scale divided into stages of seven years each. The first stage involves primarily physical development (walking, hand skills, aspiration to imitate); the second seven-year period activates the inner processes involving reshaping and development of inclinations, habits, conscience, character, memory, and temperament; the third stage is a time of mental and emotional maturing, which corresponds to the emotional probing and ripening of adolescence; and the last stage relevant to the educational process draws on the powers of the human Self relating to adulthood. Like Marie Montessori, Rudolf Steiner was well aware of the need to approach students with the use of teaching matter adequate for each particular stage of development, believing that if these educational opportunities were either neglected or ignored, it would have negative impact on the individual's development as well as on his or her readiness and willingness to learn. Later on in life, it would also afflict their positive self-confidence, mental flexibility, and creativity. For her part, Marie Montessori defined these stages of development as the period of sensitivity, assuming that if the teacher imparted to his students information centered around themes typical for this sensitive period, the latter were eager to work and made good progress with relative ease. For a child to develop this sensitivity in the proper healthy manner, it was up to the tutor or teacher to exert due influence on the child's will, and intellectual and emotional capacities.

Rudolf Steiner's method of teaching was based on elements pertinent to the domain of music, on which he modeled the standard pattern of a school 
lesson. To him, the teacher's conscious work with these elements was instrumental in strengthening the students' will and their capacity to absorb ideas in the form of new teaching matter, with a view ultimately to engaging personal experience leading to fulfillment in the emotional dimension. Under this system, the prime musical elements likely to address the child on a comprehensive scale, are RHYTHM, MELODY, and HARMONY. Rhythm, as the vehicle of will, awakens activity, dynamism and attention; melody corresponds to thinking, the capacity to absorb, create and connect. Finally, harmony projects emotional experience, the world of imagination and images of the mind. That which awakens in the sphere of the will, is enriched by the thought, and settles down through experience. This trilateral approach to teaching results in its comprehensiveness, all-roundedness, and the unreserved involvement of all aspects of the human personality in the process. In the Waldorf school, these principles govern the structure of the teaching lesson. Its first five to fifteen minutes is devoted to the rhythmic part, offering room for revision, memory exercise, and a process of variation involving specific themes of study. The following 20-30 minutes is taken up by the learning, or melodic stage; and the final ten minutes, or the harmonic stage, is reserved for experience, emotional absorption, imagination.

Let's now try and take this pattern of a school lesson as a source of inspiration for the teaching of specific subjects, to demonstrate the ways whereby a creative teacher working under any educational system can make use of this phenomenon.

Czech language teaching. In the rhythmic part, the teacher will pick the form of rondo. In music, this is a compositional genre based on the continuous repetition of Part A, with the successive interposition of parts B, C, D and so on, which bring into play the element of variation. In the case of Czech language, it may be for instance the continually recurrent motif of the syllables $H Y, C H Y, K Y, R Y, D Y, T Y, N Y$ representing Part A of the rondo form, and words formed individually by students, as the interposed variables: e.g., rychlost (B), hydrant (C), tykev (D), yielding a game pattern such as A B A C A D, where Part A involves the whole class, whereas the other parts are assigned to soloists, or individual students. Whenever the teacher works with a group, Part A is invariably common for all students, with the group defining their own input in accord with a specific set subject. Students may accompany each occurrence of the main theme by various manifesta- 
tions, such as a movement, a hand-clap, a tap, a marching step, etc. What is essential in the process is the constant presence of rhythmic pulsation as an auxiliary element in the transition from common activities to solo and group performance. The teacher should never forget to offer students time for reflection. The rondo form can thus be applied for instance to exercises involving words sharing a common initial letter, or words sharing a particular morphological feature; or elsewhere, it may serve as a vehicle for the training of variation on the lexicological level overlapping to the semantic, offering a wide scope of variational options. Similarly, the rondo form can likewise be used in a "question and answer" game, where the question will be common for the whole class, while the answer will be provided by an individual student or a group. Both the teacher and students are free to suggest one of an endless repertoire of questions or themes (such as, "Which irregular verbs do you know?" or "Invent an interjection, a verb, a noun," etc.). More elaborate patterns include a rhythmic relay, where Part A occurs at the start and is then followed up in continual sequence by Parts B, C, D, E, then the recurrence of the common Part A, succeeded by Parts F, G, H, I, with the students passing on an imaginary relay post. Another variant is the forming of a "snake," with Part A occurring only at the start and then at the end, the individual answers and suggestions following each other in continual sequence. Thus every student gets a chance to be heard, while at the same time respecting the team as a whole, being part of it.

The format of variations on a theme encourages active involvement, promptness, the capacity to work with words, concepts and themes, flexibility, and the awareness of being part of a whole; its sense of rhythmic order implies the individual's free choice of opinion. It exemplifies the principle of team work governed by clearly defined rules. The rhythmic aspect may also involve such variants as the rhythming of limericks and nursery rhymes, common recitation of a text, declamation of the alphabet, or teachers and students inventing their own rhymes. Teachers in Waldorf schools often make short rhymes, and students are involved in group recitation of very short stories. Teacher and class may thus recite a text, and clap their hands, jump up or squat down at each occurrence of, say, a verb. Identical approach can be applied to other parts of speech as well: a noun is signaled by a step forward, an adjective by a step back, a verb by a more dynamic movement, like a skip, and so on. Moreover, devices such as glockenspiel can be used for greater variety and to enhance the element of playfulness. The teacher utters 
simple sentences, with the class divided into three groups, each representing a definite part of speech manifested by a specific tone: a noun $=\mathrm{C} 1$, an adjective $=\mathrm{E} 1$, a verb $=\mathrm{G1}$; "Auntie's dancing a fine jig" (C-G-E-C).

In its turn, the melodic part offers room for the reception of new information. Following the active start of the lesson which involved all students, the class concentrates on more intensive work. A first-form student, who was in the opening part engaged in inventing words starting with " $T$ ", reciting rhymes containing these words, painting imaginary letters in the air, tiptoeing to a rhythm, and shooting an arm up staccato-like in an attempt at "hitting the sun" with a particular letter, can now, in the second part, fully concentrate on writing.

The harmonic part may bring up a story, like the one about Little Tony building a tunnel with dry grass, his dad helped him out, while aunt and little Theresa picked cherries, and a long line of poplars pointed up to the sky. The children listen to what they will next time paint, and then act out as a drama sketch; they can sing a song or listen to a piece of music whose staccato motif resembles a short, cheerful " $\mathrm{T}$ ".

Mathematics. Movement and rhythm are the best track to the world of numbers. The way a child learns to count sets the groundwork for his patterns of thought in adulthood. It is here that foundations are already being laid for a grown-up individual's concept of the world, whether it will be atomistic, or synoptic. A better understanding of numbers and their meanings can be achieved most notably with the help of various rhythmic actions and elements of "playing" one's own body, as an instrument. Let's take a few examples:

- children form a circle, counting from one to twenty, clapping their hands on every even number

- students walk in circle, counting, stamping their foot on every third number (alternatively, they may snap their fingers, hunch down, skip, etc.)

- children line up and follow the teacher marching forward, counting one, two, three, four (one step - one number), then walk back, this time counting four, three, two, one; at the next stage, they carry on, again in the progressive order, starting from number five (five, six, seven, eight; and back, eight, seven, six, five); then restart from nine, thirteen, and finally, seventeen

- students form a circle, taking turns in calling out numbers from one to twenty; the one who calls one claps, number two slaps his belly, number three slaps his thighs, number four stamps (five $=$ hand clap, six $=$ belly 
slap, seven = thigh slap, eight = stamp, etc. ); the process is repeated several times over, so all children take their turns at the various elements; counting in reverse order may ensue

- the teacher plays a simple tune on the recorder; after a while he/she will cease playing, and students are asked to count the notes that have been lost.

In exercises involving numbers, a wide range of aids can be used other than the student's body. Preferably, these are made of natural materials, such as different kinds of nuts, berries, marbles, small packets filled with miscellaneous stuff, etc.

The teaching of multiplication is particularly interesting, since naturally enough, neither there should the process be focused on imparting a purely mechanical skill, but should once again involve an appropriate type of exercises. Under the teacher's supervision, students themselves can invent such exercises, which is a hugely popular approach. Thus for instance:

- students walk along a square-shaped perimeter, counting, calling out loud every multiple of the number four, then moving on along the adjoining side of the square (one, two, three, four = one side; five, six, seven, eight = next side; nine, ten, eleven, twelve = next side; the counting goes on up to number 40)

- children form a circle, taking turns in counting from one to sixty; the task will be for each student whose turn will be a multiple of six, will hunch down; multiple values and types of the students' movements are altered according to need

- the whole class move in circle, counting aloud; on each number, they make a small skip, on multiples of four they stamp their feet; the process is then repeated in reverse (both the counting and the movements)

Exercises may be carried out in groups of two, three or larger, either with all groups being assigned the same task, or with each group inventing their own exercise which they will subsequently teach to the rest.

The lesson's melodic part will then bring the actual arithmetic training, acquisition of new mathematical skills, or solution of problems which are thematically related to the general elementary curriculum, to the characteristics of the current season of the year, festivals and holidays, etc. 
The harmonic part will survey the world of numbers from the perspective of stories and images: One is Earth; one is Sun; one is Mother, which may entail a solo instrument performance, or alternatively, a duo, trio or quartet with stories involving the corresponding numbers.

The rondo form, rhythmic relays, the game of echo, rhyme rhythming, or games with words, concepts and themes, are all helpful in the teaching of foreign languages, elementary teaching or local history and geography. In all of these subjects, though, the time reserved for the actual teaching of new subject matter should be followed by adequate space offered to acting, singing, listening, drawing, body movement, and miming.

Any activity combining the elements of will, thought and feeling implies the awareness and concept of wholeness, contributing to the individual's harmonious development, and consolidating newly acquired knowledge. It will likewise embrace the attributes of playfulness, personal experience, and discovery.

"The development of the faculty of thinking receives a good deal of attention in the process of education. In the aftermath of the debacle of the last decades, new ways are now being sought leading to the development of moral powers. And yet, all of this is worthless if these powers do not go hand in hand with a healthy, fully developed emotional life of the human individual. The teacher must never bring the teaching process to a halt at the peak of suspense. $\mathrm{He} / \mathrm{she}$ has to carry the suspense (attention) to its extreme, and then to prepare the ground for relief. If he/she fails to do so, the children will burst out of the classroom and bring the whole school down. Indeed, the teacher must compose his/her lesson so as to turn it into a kind of a little symphony, or a sonata, complete with an introduction, a middle part, and a finale." (Bernard CJ Lievegoed, Phases of Childhood/Vývojové fáze ditěte, Baltazar, Prague 1992). The prospects of a new study opened up within this context represent a major challenge with a view to drawing up a methodology, theoretical cornerstones and musical listening material that would duly reflect this phenomenon. Last but not least, they invite us teachers to spark off an impulse for a truly creative work with students, leading up to a situation where the latter would draw on the newly acquired principles while engaging in their own creative work, tuned to their specific needs in the field, in their classrooms. 


\section{Bibliography}

1. BOOGERD, C. Éterné tělo ve výchově malých dětí. Hranice: Fabula 2009. ISBN 978-80-86600-55-0. p. 208.

2. BUERMANN, U. Jak prežít s medii ("Aubrecht durch die Medien"). Hranice: Fabula 2009. ISBN 978-80-86600-58-1. p. 232.

3. HRADIL, R. Lidstvo na rozcestí. Hranice: Fabula 2009. ISBN 978-80-86600-57-4. p. 239.

4. KASPER, T., KASPEROVÁ, D. Dẽjiny pedagogiky. Praha: Grada 2008. ISBN 978-80-247-2429-4. p. 224.

5. KOLEKTIV AUTORŮ, Utváŕení výuky v 1. až 8. tř́dě waldorfské školy ("Zur Unterrichtsgestaltung im 1. bis 8. Schuljahr am waldorf/Rudolf Steiner Schulen"). Ostrava: Pedagogická fakulta, 1998. p. 232.

6. LIEVEGOED, B. C. J. Vývojové fáze ditěte ("Ontwikkelingsfasen van het kind"). Praha: Baltazar, 1992. ISBN 80-900307-7-7. p. 162.

7. RICHTER, T. Učební plán waldorfské školy ("Lehrplan Waldorf/Rudolf Steiner Schulen"). Semily: Opherus 2000. p. 392.

8. RIST, M. Trojčlennost a svoboda člověka ("Schritte zu einer geistgemässen Sozialökonomie"). Hranice: Fabula 2000. ISBN 80-238-5150-0. p. 138.

9. STEINER, R. Gesenwärtiges Geistesleben und Erziehung ("Duchovní život a výchova v prítomnosti"). GA 307. Unpublished translation. p. 255.

10. STEINER, R. Výchova dítěte a metodiky vyučování ("Die Methodik des Lehrens und die Lebensdingungen des Erziehens"). Praha: Baltazar, 1993. ISBN 80-900307-9-3. p. 120.

11. STEINER, R. Všeobecná nauka o člověku jako základ pedagogiky ("Allgemeine Menschenkunde als Grundlage der Pedagogik"). GA 293. Semily: Opherus, 2003. ISBN 80-902647-8-6. p. 256.

12. STEINER, R. Die geistig-seelischen Grundkräfte der Erziehungkunst. Spirituelle Werte in Erziehung und sozialem Leben ("Waldorfská pedagogika"). GA 305. Unpublished translation. p. 156.

13. STEINER, R. Kunst und Kunsterkenntnis. Grundlagen einer neuen Ästhetik GA 271 (Umèní. Základ nové estetiky). Dornach: Rudolf Steiner Verlag, 1961. Unpublished translation. p. 97.

14. STEINER, R. Kunst im Lichte der Mysterienweisheit GA 275 (Umění ve světle mysterii). Dornach: Rudolf Steiner Verlag, 1963. Unpublished translation. p. 123. 
15. STEINER, R. Waldorfská pedagogika ("Erziehungskunst") GA 295. Semily: Opherus 2006. ISBN 80-902647-9-4. p. 204.

16. STEINER, R., kolektiv autorů Terapie duše ("Die mission des Zomes"). Hranice: Fabula 2001. ISBN 80-902829-9-7. p. 195.

17. STREIT, J. Proč dèti potřebují pohádky ("Warum Kinder Märchen brauchen"). Praha: Baltazar, 1992. ISBN 80-900307-4-2. p. 80.

18. ZUZÁK, T. Osud člověka a individualita. Hranice: Fabula 2009. ISBN 978-80-86600-61-1. p. 126.

\section{Reference list}

Technická univerzita v Liberci, FPHP, Katedra primárního vzdělávání

Univerzita J. E. Purkyně v Ústí nad Labem, PF, Katedra hudební výchovy

\section{Contact}

Jana Konvalinková, MgA.

Technická univerzita v Liberci, FPHP, Katedra primárního vzdělávání

Studentská 2, 46001 Liberec I

Tel. 485354439

e-mail: jana.konvalinkova@tul.cz 